\title{
Sulfur bacteria in wastewater stabilization ponds periodically affected by the 'red-water' phenomenon
}

\author{
Abdelaziz Belila $\cdot$ Ben Abbas $\cdot$ Imed Fazaa . \\ Neila Saidi • Mejdi Snoussi • Abdennaceur Hassen • \\ Gerard Muyzer
}

Received: 13 December 2011 / Revised: 27 January 2012 / Accepted: 28 January 2012 / Published online: 23 February 2012

(C) The Author(s) 2012. This article is published with open access at Springerlink.com

\begin{abstract}
Several wastewater stabilization ponds (WSP) in Tunisia suffer periodically from the 'red-water' phenomenon due to blooming of purple sulfur bacteria, indicating that sulfur cycle is one of the main element cycles in these ponds. In this study, we investigated the microbial diversity of the El Menzeh WSP and focused in particular on the different functional groups of sulfur bacteria. For this purpose, we used denaturing gradient gel electrophoresis of PCR-amplified fragments of the 16S rRNA gene and of different functional genes involved in microbial sulfur metabolism $(d s r \mathrm{~B}, \operatorname{apr} \mathrm{A}$, and puf $\mathrm{M}$ ). Analyses of the $16 \mathrm{~S}$ rRNA revealed a relatively high microbial diversity where Proteobacteria, Chlorobi, Bacteroidetes, and Cyanobacteria constitute the major bacterial groups. The $d s r \mathrm{~B}$ and aprA gene analysis revealed the presence of deltaproteobacterial sulfate-reducing bacteria (i.e., Desulfobacter and Desulfobulbus), while the analysis of $16 \mathrm{~S}$ rRNA, aprA, and pufM genes assigned the sulfuroxidizing bacteria community to the photosynthetic
\end{abstract}

Electronic supplementary material The online version of this article (doi:10.1007/s00253-012-3931-5) contains supplementary material, which is available to authorized users.

A. Belila $(\triangle) \cdot$ I. Fazaa $\cdot$ N. Saidi $\cdot$ M. Snoussi $\cdot$ A. Hassen Water Treatment and Reuse Laboratory,

Water Researches and Technologies Centre of Bordj-Cedria, BP. 273, 8020, Soliman, Tunisia

e-mail: belilaziz@yahoo.com

B. Abbas $\cdot$ G. Muyzer

Department of Biotechnology, Delft University of Technology, NL-2628 BC Delft, The Netherlands

G. Muyzer

Department of Aquatic Microbiology,

Institute for Biodiversity and Ecosystems Dynamics,

University of Amsterdam,

NL-1098 XH Amsterdam, The Netherlands

e-mail: g.muijzer@uva.nl representatives belonging to the Chlorobi (green sulfur bacteria) and the Proteobacteria (purple sulfur and non sulfur bacteria) phyla. These results point on the diversity of the metabolic processes within this wastewater plant and/or the availability of sulfate and diverse electron donors.

Keywords Sulfur bacteria $\cdot$ PCR-DGGE $\cdot$ Functional diversity $\cdot$ Red-water phenomenon $\cdot$ Wastewater stabilization ponds

\section{Introduction}

Wastewater stabilization ponds (WSPs) are an extremely effective, natural form of wastewater treatment. They combine simplicity, robustness, and low cost with a very high degree of purification. They rely upon the natural ability of a shallow water body to achieve self-purification, whereby light penetration is of fundamental importance (Curtis et al. 1994). WSPs are usually designed as one or several series of anoxic, facultative, and maturation ponds, with the first two being mainly responsible for the removal of suspended solids and organic matter (biological oxygen demand) and the last one for the removal of pathogens and nutrients. Their low operation and maintenance costs have made them a popular choice for wastewater treatment, particularly in developing countries, since there is little need for specialized skills to operate these systems. WSP systems are widely used in Mediterranean countries (Mara 2008); in Tunisia, they account for more than 25\% of the wastewater treatment plants (ONAS 2009). However, although these systems are very effective in the treatment of wastewater, they sometimes suffer from severe problems, such as the 'red-water' phenomenon.

The 'red-water' phenomenon is a temporal change in water color resulting from the massive growth ('blooming') 
of phototrophic anoxygenic purple bacteria. This bacterial phenomenon has been observed in several different wastewater stabilization ponds (Veenstra et al. 1995). The 'redwater' phenomenon is a sign of process failure causing malfunction of the wastewater treatment (Belila et al. 2009). The phenomenon is caused when the WSP system is overloaded with organic material, which stimulates sulfate reduction in the anoxic and facultative ponds. Consequently, the rising sulfide concentration is toxic for the algae but stimulates the growth of phototrophic sulfur bacteria that flourish under these anoxic conditions (Villanueva et al. 1994). The red-water phenomenon causes a deterioration of the effluent quality, i.e., red-colored water, a strong hydrogen sulfide smell, and high concentrations of suspended solid (Nair 1992).

The sulfate-reducing and the sulfur-oxidizing bacteria (SOB) encompass phylogenetically and physiologically diverse groups. The first group fall into three major branches: the delta-subclass of Proteobacteria, the Grampositive bacteria, and branches formed by the thermophilic Archaeal sulfate-reducing bacteria (SRB) (Tang et al. 2008), while the taxonomic affiliation of sulfur-oxidizing bacteria has a broad range, from $\alpha-, \beta-, \gamma-, \varepsilon$-proteobacteria, and Chlorobia to Chloroflexi (Ghosh and Dam 2009; Vannini et al. 2008). Both bacterial guilds are of immense importance from the industrial and environmental points of view and thrive in a wide variety of natural and engineered ecosystems (Asano et al. 2007; Ben-Dov et al. 2007). Their ecological and biogeochemical importance was recognized early due to their key role in the nitrogen, carbon, and sulfur cycles (Madigan 1995).

The anoxygenic phototrophic bacteria (APB) are responsible for the oxidation of sulfide as a major biogeochemical activity in aquatic ecosystems (Pierson and Olson 1987) since most known groups of APB, such as the purple sulfur, the purple non-sulfur, the green sulfur, and green non-sulfur bacteria, are able to use reduced sulfur compounds as electron donors for anoxygenic photosynthesis (Dahl and Prange 2006; Sander and Dahl 2008).

A wide variety of molecular tools have been applied to assess the diversity of bacteria involved in the sulfur cycle by targeting the16S rRNA gene (Dar et al. 2007; Lücker et al. 2007). However, the lack of phylogenetic coherence among both bacterial guilds and the different metabolic pathways involved in the oxidative and reductive processes of the sulfur cycle limit the use of 16S rRNA genes for the detection and the ecophysiological assignment of these bacteria. Targeting functional genes implicated in the microbial sulfate reduction and sulfur oxidation processes is a better strategy to analyze the phylogenetic complexity of bacteria of the sulfur cycle, specifically the sulfate-reducing and the sulfur-oxidizing bacteria (Kubo et al. 2011; Miletto et al. 2007). Functional genes such as $d s r \mathrm{~B}$ (Geets et al. 2006),
Sox (Meyer et al. 2007), aprA (Meyer and Kuever 2008), and pufM (Ranchou-Peyruse et al. 2006) have been successfully applied to resolve the genetic diversity of both sulfatereducing and sulfur-oxidizing bacteria.

The dissimilatory sulfite reductase (DSR) and adenosine5 '-phosphosulfate (APS) reductase are two keys enzymes in microbial sulfate reduction and sulfur oxidation processes, highly conserved among the sulfate-reducing and the sulfuroxidizing bacteria, and consequently $d s r \mathrm{AB}$ and $a p r \mathrm{AB}$ genes constitute the most suitable targets for molecular profiling of the microbial community structure of the sulfur cycle in the environment (Meyer and Kuever 2007a). In addition, the puf $\mathrm{M}$ gene encoding the $\mathrm{M}$ subunit of the photosynthetic reaction center in purple sulfur and purple non-sulfur bacteria (Corson et al. 1999) has been successfully applied to the phylogenetic characterization of phototrophic bacterial communities in aquatic environments.

So far, most studies on WSP systems have concentrated on the fate and removal of pathogenic microorganisms, such as fecal enterococci, Cryptosporidium, Giardia (Anceno et al. 2007; Reinoso and Bécares 2008), and helminth eggs (e.g., Taenia, Ascaris, and Trichuris) (Tyagi et al. 2008). However, here we present for the first time a detailed study on the microbial communities present in WSP systems. We focused on the bacterial diversity during 'red-water' phenomenon occurrence and especially on the diversity of the sulfate-reducing and the sulfur-oxidizing bacteria.

\section{Materials and methods}

Wastewater stabilization ponds

Our study was carried out in a wastewater stabilization pond (WSP) system located in the city Mutuelleville in north-east of Tunisia $\left(36^{\circ} 49^{\prime} \mathrm{N}, 10^{\circ} 10^{\prime} \mathrm{E}\right)$. The WSP system consists of four inter-connected ponds: an anaerobic, a facultative, and two maturation ponds. The geometric characteristics of these ponds are summarized in Table 1 . The system mainly receives wastewater of domestic origin, i.e., 'black' water (water from toilets) and 'grey' water (domestic sewage). The wastewater fills up the first, anoxic (A) pond, then

Table 1 Geometric characteristics of the wastewater stabilization ponds

\begin{tabular}{llll}
\hline & $\begin{array}{l}\text { Anaerobic } \\
\text { pond }\end{array}$ & $\begin{array}{l}\text { Facultative } \\
\text { pond }\end{array}$ & $\begin{array}{l}\text { Maturation } \\
\text { pond }\end{array}$ \\
\hline Surface $\left(\mathrm{m}^{2}\right)$ & 30 & 100 & 122 \\
Depth $(\mathrm{m})$ & 3.5 & $2.34-1.44$ & 1.34 \\
Volume $\left(\mathrm{m}^{3}\right)$ & 96 & 180 & 164 \\
Water depth $(\mathrm{m})$ & 3.3 & 2 & 1.15 \\
\hline
\end{tabular}


enters the secondary facultative $(\mathrm{F})$ pond through an outflow, and subsequently enters the maturation (M) pond. Finally, the treated water is released in a small river.

\section{Environmental sampling}

For molecular analysis, 16 samples were collected in April 2009. Five sediment samples each were collected from the anaerobic $\left(\mathrm{S}_{\mathrm{A} 1}\right.$ to $\left.\mathrm{S}_{\mathrm{A} 5}\right)$ and from the facultative pond $\left(\mathrm{S}_{\mathrm{F} 1}\right.$ to $\left.\mathrm{S}_{\mathrm{F} 5}\right)$ with a Plexiglas core tube $(5 \mathrm{~cm}$ in diameter and $20 \mathrm{~cm}$ in length). Sediment samples were taken from the middle and each corner of the basins. The sediment layers within the maturation ponds were very thin and could not be sampled. Six water samples $\left(\mathrm{W}_{\mathrm{A}}, \mathrm{W}_{\mathrm{F}}, \mathrm{W}_{\mathrm{M} 1}, \mathrm{~W}_{\mathrm{M} 2}, \mathrm{~W}_{\mathrm{M} 3}\right.$, and $\mathrm{W}_{\mathrm{M} 4}$ ) were collected and pre-filtered through polycarbonate filters $(0.8 \mu \mathrm{m}$ in pore size $)$ to exclude debris.

Physical and chemical parameters

The in situ temperature and $\mathrm{pH}$ were measured with a handheld $\mathrm{pH}$ and temperature meter (WTW 340i model, WTW, Weilheim, Germany). The dissolved oxygen (DO) concentration was determined using a Multiline F/set P4 universal meter (WTW, Weilheim, Germany). The 5-day biochemical oxygen demand $\left(\mathrm{BOD}_{5}\right)$, chemical oxygen demand (COD), and total suspended solids (TSS) as well as the sulfate and sulfide concentrations were determined according to the analytical methods described in "Standard Methods for the Examination of Water and Wastewater" (APHA 1995). Chlorophyll $a$ concentration was estimated by the methanol extraction method (Pearson 1986).

\section{Nucleic acid extraction}

Prior to DNA extraction, water samples $(250 \mathrm{ml})$ were centrifuged at $13,500 \mathrm{rpm}$ at $4{ }^{\circ} \mathrm{C}$. A total of $0.5 \mathrm{~g}$ of concentrated biomass and the same quantity of sediments were used for DNA extraction by using the UltraClean Soil DNA Extraction Kit (MOBIO Laboratories, Inc., CA, USA) according to the manufacturer's instructions.

\section{PCR amplification}

Amplification of $16 \mathrm{~S}$ rRNA and $d s r \mathrm{~B}$ gene fragments was performed using the primer pairs $341 \mathrm{~F}-\mathrm{GC}$ and $907 \mathrm{R}$ (Muyzer et al. 1995) and DSRp2060F-GC and DSR4R (Wagner et al. 1998), respectively. For the amplification of the $d s r \mathrm{~B}$ gene, a "touchdown" protocol was used, wherein the annealing temperature was decreased from 65 to $55^{\circ} \mathrm{C}$ in 20 cycles. Thermal cycling was carried out as follows: 5 min of initial denaturation at $95^{\circ} \mathrm{C}$, followed by 20 cycles of denaturation at $95{ }^{\circ} \mathrm{C}$ for $40 \mathrm{~s}$, a "touchdown" annealing step for $40 \mathrm{~s}$, and elongation at $72{ }^{\circ} \mathrm{C}$ for $1 \mathrm{~min}$. This was followed by another 30 cycles of denaturation at $95^{\circ} \mathrm{C}$ for $40 \mathrm{~s}$, annealing at $55^{\circ} \mathrm{C}$ for $40 \mathrm{~s}$, and elongation at $72{ }^{\circ} \mathrm{C}$ for 1 min (Dar et al. 2007). Amplification was completed by a final elongation step at $72{ }^{\circ} \mathrm{C}$ for $10 \mathrm{~min}$. DNA from Desulfobulbus propionicus was used as a positive control and deionized water as a negative control in all PCR amplifications. A 'touchdown' PCR protocol was used to amplify aprA gene fragments using primers AprA-1-FW and AprA5-RV-GC (Meyer and Kuever 2007c). Thermal cycling was carried out as follows: 5 min of initial denaturation of DNA at $95^{\circ} \mathrm{C}$, followed by 35 cycles of denaturation at $95^{\circ} \mathrm{C}$ for $60 \mathrm{~s}$, a 'touchdown' annealing step for $90 \mathrm{~s}$ (annealing temperature was decreased in the first 20 cycles by $0.5^{\circ} \mathrm{C}$ until reaching $50{ }^{\circ} \mathrm{C}$ in every cycle, while the subsequent 15 cycles were carried out at constant temperature), and elongation at $72{ }^{\circ} \mathrm{C}$ for $120 \mathrm{~s}$. Amplification was completed by a final elongation step at $72{ }^{\circ} \mathrm{C}$ for $10 \mathrm{~min}$. Primer set pufM557F and pufM750R was used to amplify the photosynthetic unit-forming gene ( $p u f \mathrm{M}$ ) of purple phototrophic bacteria (Achenbach et al. 2001). PCR was performed by using an initial denaturation step at $95^{\circ} \mathrm{C}$ for $15 \mathrm{~s}$, followed by 35 amplification cycles of denaturation $\left(95^{\circ} \mathrm{C}\right.$ for $\left.1 \mathrm{~min}\right)$, annealing $\left(54{ }^{\circ} \mathrm{C}\right.$ for $\left.30 \mathrm{~s}\right)$, elongation $\left(72{ }^{\circ} \mathrm{C}\right.$ for $\left.1 \mathrm{~min}\right)$, and a final extension step at $72{ }^{\circ} \mathrm{C}$ for $10 \mathrm{~min}$. Amplifications were performed in Biometra $\mathrm{T}$ Gradient Thermocycler (Biometra $\mathrm{GmbH}$, Germany), and PCR products were verified on $1 \%$ or $2 \%(w / v)$ agarose gel in $1 \times$ Tris/acetate/EDTA (TAE) buffer.

\section{Denaturing gradient gel electrophoresis}

All DGGE experiments were performed with the D-Code system (Bio-Rad Laboratories, CA, USA). For the 16S rRNA, electrophoresis was performed with $6 \%$ polyacrylamide gels (ratio of acrylamide to bisacrylamide, 40:1) submerged in $1 \times$ TAE buffer $(40 \mathrm{mM}$ Tris, $40 \mathrm{mM}$ acetic acid, 1 mM EDTA, $\mathrm{pH} 7.5$ ) at a constant temperature of $60^{\circ} \mathrm{C}$. The electrophoresis conditions for gene fragments were: $16 \mathrm{~h}$ at $100 \mathrm{~V}$ in a linear $20 \%$ to $80 \%$ denaturant gradient $(100 \%$ denaturant was a mixture of $7 \mathrm{M}$ urea and $40 \%[v / v]$ formamide) (Schäfer and Muyzer 2001). However, for $d s r \mathrm{~B}$ gene fragments, a gradient of 35-80\% denaturant (the $100 \%[\mathrm{w} / \mathrm{v}]$ denaturing solution contained $7 \mathrm{M}$ urea and $40 \%[v / v]$ formamide) was constructed in a 1.5 -mm-thick $8 \%$ polyacrylamide gel. The gel was initially run at $150 \mathrm{~V}$ for $5 \mathrm{~min}$ to facilitate the access of PCR products into the gel and then at a constant voltage of $75 \mathrm{~V}$ for $30 \mathrm{~h}$ in a $0.5 \times$ TAE buffer at a stable temperature of $60{ }^{\circ} \mathrm{C}$ (Miletto et al. 2007). For pufM gene fragments, samples were electrophoresed on a $10 \%$ polyacrylamide gel with $20 \%$ to $80 \%$ denaturant $(100 \%$ denaturant was $7 \mathrm{M}$ urea and $40 \%[v / v]$ formamide) at $130 \mathrm{~V}$ for $8 \mathrm{~h}$ at $60{ }^{\circ} \mathrm{C}$ (Karr et al. 2003). For aprA, a double-gradient DGGE was used with a linear polyacrylamide gradient of $6-8 \%$ and a 
linear denaturant gradient of 30-60\% (100\% denaturant was $7 \mathrm{M}$ urea and $40 \%[v / v]$ formamide. Electrophoresis was performed at $60{ }^{\circ} \mathrm{C}$ for $2 \mathrm{~h}$ at $150 \mathrm{~V}$ and subsequently for $2 \mathrm{~h}$ at $200 \mathrm{~V}$. All DGGE gels were stained with SYBR Green I (Sigma-Aldrich Corporation, St. Louis, MO, USA) and were visualized on a UV transilluminater. Individual bands were excised, re-suspended in $20 \mu \mathrm{l}$ of Milli-Q water, and stored overnight at $4{ }^{\circ} \mathrm{C}$. A volume of 3 to $5 \mu \mathrm{l}$ of the supernatant was used for re-amplification using the original PCR conditions and primer pair without a GC clamp and then photographed using a G:BoxiChemi 2D gel image analyzer using Genesnap software 7.03 (SYNGENE, Synoptics, Ltd, Cambridge, UK).

Comparative sequence analysis

Sequences obtained from the excised DGGE bands were first compared to sequences stored in the publicly accessible database GenBank using the NCBI BLAST search tool (http://blast.ncbi.nlm.nih.gov/Blast.cgi). Subsequently, the sequences were imported into the ARB software package (Ludwig et al. 2004) and aligned using the automatic aligner function. The phylogenetic trees were constructed on the basis of long (more than 1,300 bp) sequences using different methods integrated within the ARB software. Partial sequences obtained in this study were then inserted into the pre-established tree using the ARB parsimony tool.

GenBank accession numbers

The nucleotide sequence data are available under the GenBank accession numbers, HQ222639 to HQ222674 (dsrB), HQ222675 to HQ222729 (pufM), HQ222613 to HQ222638 (aprA), and HQ222730 to HQ222810 (16S rDNA).

\section{Results}

Performance of the wastewater stabilization pond system

The performances of the wastewater stabilization pond system investigated in April 2009 were unsatisfactory regarding to the BOD and COD removal efficiency (Table 2). The chemical and biological parameters within the stabilization ponds gave evidence of a eutrophic state. The system performance decreased during this period of the year and the percentage removal of the TSS as well as the biological and chemical oxygen demands $\left(\mathrm{BOD}_{5}\right.$ and $\left.\mathrm{COD}\right)$ were unsatisfactory $(50 \%, 40 \%$, and $43 \%$, respectively). The proliferation of the purple red color throughout the water column, reaching up to the surface of the four ponds, supports the prevalence of anoxic conditions within the whole system. Wastewater treatment successfully enhanced $\mathrm{SO}_{4}{ }^{2-}$ removal, accounting for greater than $83 \%$ reduction in $\mathrm{SO}_{4}{ }^{2-}$ concentrations during the sampling campaign. Maximum sulfate removal $(86 \%)$ was reached within the first maturation pond (M1), showing a distinctive development of sulfates reducing conditions within this pond.

\section{DGGE analysis of 16S rRNA gene fragments}

DGGE analysis of PCR-amplified 16S rRNA gene fragments showed many different bands, between 12 and 23 per lane, indicating a high microbial diversity in the WSP system (figures of the DGGE gels are provided as "Electronic supplementary material"). Largely reproducible patterns were obtained with the five sediment samples from the anaerobic pond (lanes 1-5) and the five samples from the facultative pond (lanes 6-10). Differences within the DGGE profiles appeared more pronounced among the water samples (lanes 11-16) and between the water and the sediment samples than among the sediment samples (lanes 1-10). Several bands were detected concomitantly within different samples, although with varying intensities (i.e., bands $A_{2}, G_{2}, H_{2}, C_{2}$, and $D_{2}$ ). In total, 90 bands were excised from the denaturing gel and sequenced in order to identify the predominant community members. A total of 15 DGGE bands gave ambiguous sequences and were not included in the phylogenetic analysis.

The phylogenetic affiliation of the different community members present in the WSP system is presented in Fig. 1a, b. A total of 26 sequences $(28.8 \%)$ were attributed to different classes within the Proteobacteria (Fig. 1a), i.e., the Betaproteobacteria, the Gamma-, the Alpha-, and the Deltaproteobacteria. The other 64 sequences showed similarity with sequences from other phyla; 14 sequences

Table 2 Physical and chemical parameters of the wastewater stabilization pond system

\begin{tabular}{lllllclcccc}
\hline & $T\left({ }^{\circ} \mathrm{C}\right)$ & $\mathrm{pH}$ & $\mathrm{DO}(\mathrm{mg} / \mathrm{L})$ & $\mathrm{TSS}(\mathrm{mg} / \mathrm{L})$ & $\mathrm{BOD}_{5}(\mathrm{mg} / \mathrm{L})$ & $\mathrm{COD}(\mathrm{mg} / \mathrm{L})$ & $\mathrm{Chl} \mathrm{a}(\mu \mathrm{g} / \mathrm{L})$ & $\mathrm{SO}_{4}{ }^{2-}(\mathrm{mg} / \mathrm{L})$ & $\mathrm{S}^{2-}(\mathrm{mg} / \mathrm{L})$ & $\mathrm{Salinity}(\mathrm{mg} / \mathrm{L})$ \\
\hline $\mathrm{A}$ & $14.7 \pm 2$ & $6.9 \pm 0.2$ & $0.20 \pm 0.2$ & $533 \pm 18$ & $473 \pm 19.3$ & $908 \pm 13$ & $156 \pm 28$ & $320 \pm 33$ & $40.8 \pm 0.7$ & $2 \pm 0.4$ \\
$\mathrm{~F}$ & $13.5 \pm 1$ & $7.6 \pm 0.2$ & $2.50 \pm 0.4$ & $342 \pm 38$ & $360 \pm 19.6$ & $720 \pm 17$ & $2,634 \pm 268$ & $245 \pm 43$ & $25 \pm 0.9$ & $1.4 \pm 0.6$ \\
$\mathrm{M} 1$ & $12.2 \pm 2$ & $7.5 \pm 0.1$ & $3.10 \pm 0.3$ & $247 \pm 18$ & $283.3 \pm 11.6$ & $510 \pm 26$ & $3,456 \pm 265$ & $45 \pm 15$ & $9 \pm 3.2$ & $1.1 \pm 0.5$ \\
$\mathrm{M} 2$ & $12.9 \pm 2$ & $7.4 \pm 0.1$ & $3.10 \pm 0.9$ & $262 \pm 0.9$ & $262 \pm 18$ & $505 \pm 11$ & $3,288 \pm 345$ & $52 \pm 17$ & $10 \pm 0.7$ & $1.1 \pm 0.3$ \\
\hline
\end{tabular}

$A$ anaerobic ponds, $F$ facultative pond, $M 1$ maturation pond $1, M 2$ maturation pond 2 
(15.5\%) grouped with sequences in the phylum Chlorobi, 18 other sequences (20\%) with the phylum Bacteriodetes, 13 (14.4\%) with the phylum Cyanobacteria, 4 (4.4\%) with Bacteroidetes/Chlorobi group, 4 (4.4\%) with the phylum Spirochaeta, 3 (3.3\%) with the phylum Synergistetes, 4 $(4.4 \%)$ with the phylum Acidobacteria, 1 (1\%) with the phylum Thermotoga, and 3 (3.3\%) with uncultured bacterium partial $16 \mathrm{~S}$ rRNA gene.

The sequences corresponding to bands $\mathrm{C}_{6}, \mathrm{C}_{3}$, and $\mathrm{E}_{2}$ showed $99 \%$ and $100 \%$ similarity with uncultured Aminanaerobia bacterium 16S rRNA gene clones. The closest relative for DGGE band sequences $\mathrm{F}_{2}$ and $\mathrm{D}_{3}$ was uncultured Acidobacteria bacterium 16S rRNA gene with $99 \%$ similarity. Sequences of bands $B_{10}, C_{10}$, and $A_{5}$ had $93 \%$ and $95 \%$ similarity with uncultured cyanobacterium clone $16 \mathrm{~S}$ ribosomal RNA gene and those related to bands $\mathrm{F}_{3}, \mathrm{G}_{2}, \mathrm{E}_{6}$, and $\mathrm{F}_{6}$ showed $99 \%$ similarity with uncultured Bacteroidetes/ Chlorobi group bacterium clone. The closest relatives for bands $\mathrm{D}_{11}$ and $\mathrm{B}_{12}$ was an uncultured Burkholderiaceae bacterium with similarity percentage of $95 \%$ and $99 \%$, respectivelty. DGGE band $\mathrm{E}_{4}$ was closely related to an uncultured Chlorobiaceae bacterium with 99\% similarity while DGGE band sequence $\mathrm{C}_{12}$ showed $93 \%$ similarity with an uncultured Chromatiaceae. Band $\mathrm{F}_{8}$ sequence was closely related to uncultured Bacteroidetes bacterium 16S rRNA gene with $99 \%$ similarity. Notably, most of the 16S rRNA gene sequences were affiliated to uncluttered bacteria (Fig. 1a, b); thus, the use of this phylogenetic marker could not conclude on the physiological properties and specific biochemical pathways acting in the targeted communities.

Bacteria involved in the sulfur cycle identified within the WSP were represented by the SRB of the Deltaproteobacteria (Desulfovibrio spp.), the gammaproteobacterial purple sulfur bacteria (PSB) (Thiocapsa spp.), the alphaproteobacterial purple non-sulfur bacteria (PNSB) (Rhodobacter spp.), and the green sulfur bacteria (GSB) (Chlorobium spp.). The sequence of band $\mathrm{D}_{2}$ was closely related (96\% similarity) to a Desulfovibrio sp. Sequences corresponding to bands $\mathrm{C}_{7}$ and $\mathrm{D}_{6}$ had 95\% and $99 \%$ similarity with a sequence of Thiocapsa sp., respectively. The closest relative for bands $\mathrm{A}_{11}$ and $\mathrm{G}_{12}$ was Thiocapsa pendens ( $99 \%$ similarity). The sequence of band $\mathrm{C}_{12}$ showed $93 \%$ similarity to the sequence of an uncultured bacterium within Chromatiaceae. Members belonging to the green sulfur bacteria were, however, the most prominent group within the WSP with 11 sequences. Sequences of bands $\mathrm{C}_{1}$ and $\mathrm{H}_{3}$ had $100 \%$ and $99 \%$ similarity with the 16S rRNA sequence of Chlorobium phaeobacteroides, respectively, while the sequence of band $\mathrm{C}_{4}$ had $98 \%$ similarity with the sequence of Chlorobium limicola. The sequences of band $\mathrm{E}_{4}$ showed $99 \%$ similarity to the sequence of an uncultured bacterium within the Chlorobiaceae.
DGGE analysis of $d s r \mathrm{~B}$ gene fragments

DGGE analysis of the $d s r \mathrm{~B}$ gene fragments showed the highest diversity in sediments of the anaerobic and facultative ponds ("Electronic supplementary material"). Some of the DGGE bands (i.e., bands 1 and 2) were detected only in the sediments and not in the water phase. The SRB community composition varied significantly within all sediment samples as shown in "Electronic supplementary material", except that DGGE bands 5 and 6 were detected in all anaerobic pond sediment samples. The SRB community diversity decreased within the sediment of the facultative pond (lanes 9 and 10, "Electronic supplementary material") and then increased in the maturation pond water samples (lanes 15 and 16, "Electronic supplementary material"). The number of bands per lane varied between 4 (lane 11) and 25 (lane 7).

A total of 36 bands were sequenced and used for phylogenetic analysis. All sequences were assigned to sulfatereducing bacteria within the Deltaproteobacteria. Band 48 had a $97 \%$ similarity to the $d s r$ sequence of Desulfomicrobium macestii. The closest relative for band 1 was Desulfobacter postgatei (93\% similarity). The sequence corresponding to band 30 showed $87 \%$ similarity to Desulfotignum balticum. Five $d s r \mathrm{~B}$ sequences were assigned to the Desulfobulbus genus with similarity levels varying from $84 \%$ to $90 \%$. DsrB sequences of bands 40,41 , and 44 had $84 \%$ and $90 \%$ similarity with $D$. propionicus, respectively, while sequence of band 45 had $87 \%$ similarity with Desulfobulbus rhabdoformis. The sequence corresponding to band 24 had a similarity of $87 \%$ with uncultured Desulfobulbus sp. The sequences corresponding to bands 2, 19, 46, and 50 were affiliated to members of the genus Desulfomicrobium. The closest relative for bands 2 and 46 was Desulfomicrobium escambiense with $97 \%$ similarity. Band 19 had 93\% similarity with Desulfomicrobium sp., while band 50 showed $97 \%$ level of similarity with Desulfomicrobium sp. ADR28. Several $d s r$ B-related sequences were assigned to uncultured sulfate-reducing bacteria, such as band 3 and 14 , which had $99 \%$ and $97 \%$ levels of similarity with $d s r \mathrm{~B}$ gene sequences of uncultured sulfate-reducing bacteria, respectively. The sequence corresponding to band 15 had a similarity of $94 \%$ with Desulfococcus oleovorans Hxd3. The sequences corresponding to bands $34,35,36$, and 37 were affiliated to Desulfobotulus sapovorans, a Gram-negative fatty acid-oxidizing species (Devereux et al. 1989) which is a member of the Desulfobacteraceae family. The $d s r \mathrm{~B}$ sequences of DGGE bands 5,6 , and 8 were affiliated with an uncultured sulfate-reducing bacterium clone LGWI06 with a percentage similarity of $84 \%$, whereas DGGE bands 17 and 20 sequences were affiliated with Desulfatibacillum aliphaticivorans, an $n$-alkane- and $n$-alkene-degrading, sulfate-reducing bacterium (Cravo-Laureau et al. 2004). 
Fig. 1 Phylogenetic trees based on sequences of the 16S rRNA Proteobacteria (a), 16S rRNA, non-Proteobacteria (b), dsrB (c), $d s r \mathrm{~B}$ gene phylogenetic tree: the 'base' tree was calculated using neighbor joining algorithm on the $\sim 1,500$ positions within $1 \mathrm{~F}-4 \mathrm{R}$ primer region of the $d s r \mathrm{AB}$ gene. PAM protein correction was used together with a filter (ignoring the third base pair). The sequences derived from the DGGE gel were added, after (manual) correction, using ARB parsimony (quick add species to existing tree). For calculation, 360 positions were used also applying a filter (ignoring the third base pair). For the aprA gene phylogenetic tree: the 'base' tree was calculated using neighbor joining algorithm on the $\sim 1,109$ positions of long sequences within the AprA gene. Felsenstein correction was used together with a filter (ignoring the 3rd base pair). The sequences derived from the DGGE gel were added, after (manual) correction, using ARB parsimony (quick add species to existing tree). For calculation, maximum 242 positions were used also applying a filter (ignoring the third base pair). Bootstrap $(1,000 \times)$ analysis was performed and values were written in the tree. For the puf $\mathrm{M}$ gene phylogenetic tree: the 'base' tree was calculated using neighbor joining algorithm on the $\sim 632$ positions of long sequences within the puf $\mathrm{M}$ gene. Felsenstein correction was used together with a filter (ignoring the third base pair). The sequences derived from the DGGE gel were added, after (manual) correction, using ARB parsimony (quick add species to existing tree). For calculation, a maximum of 518 positions (or as many as were available) were used also applying a filter (ignoring the third base pair) aprA (d), and pufM (e). For the

A

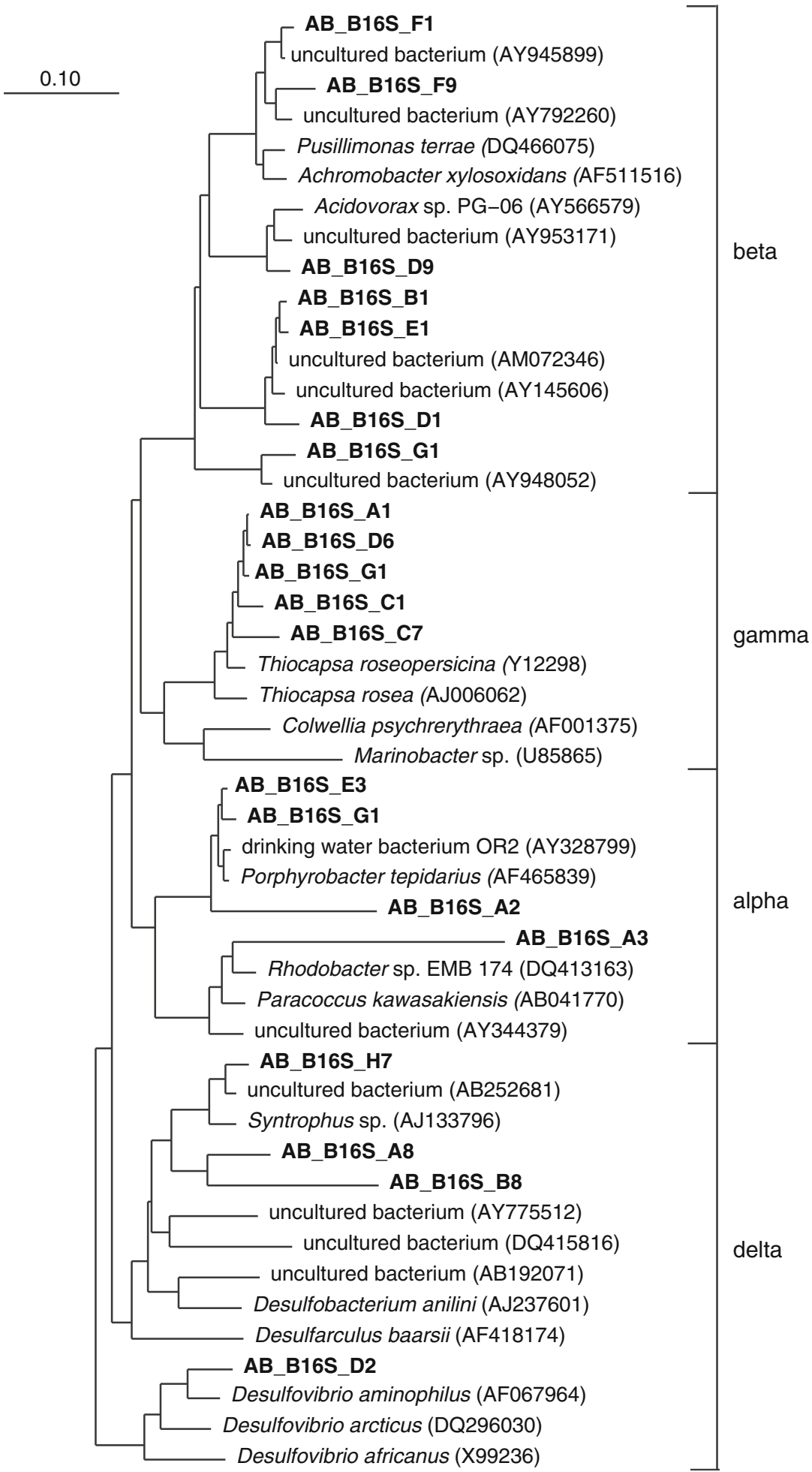

The $d s r \mathrm{~B}$ sequences of bands 7 and 13 were assigned to the Desulfosarcina/Desulfococcus cluster. The dsrB band 51 showed $94 \%$ similarity with Desulfofustis glycolicus. No Gram-positive spore-forming SRB were detected.
DGGE analysis of aprA gene fragments

Because sulfate-reducing as well as sulfur-oxidizing prokaryotes use APS reductase, the genes of this reversible 
B

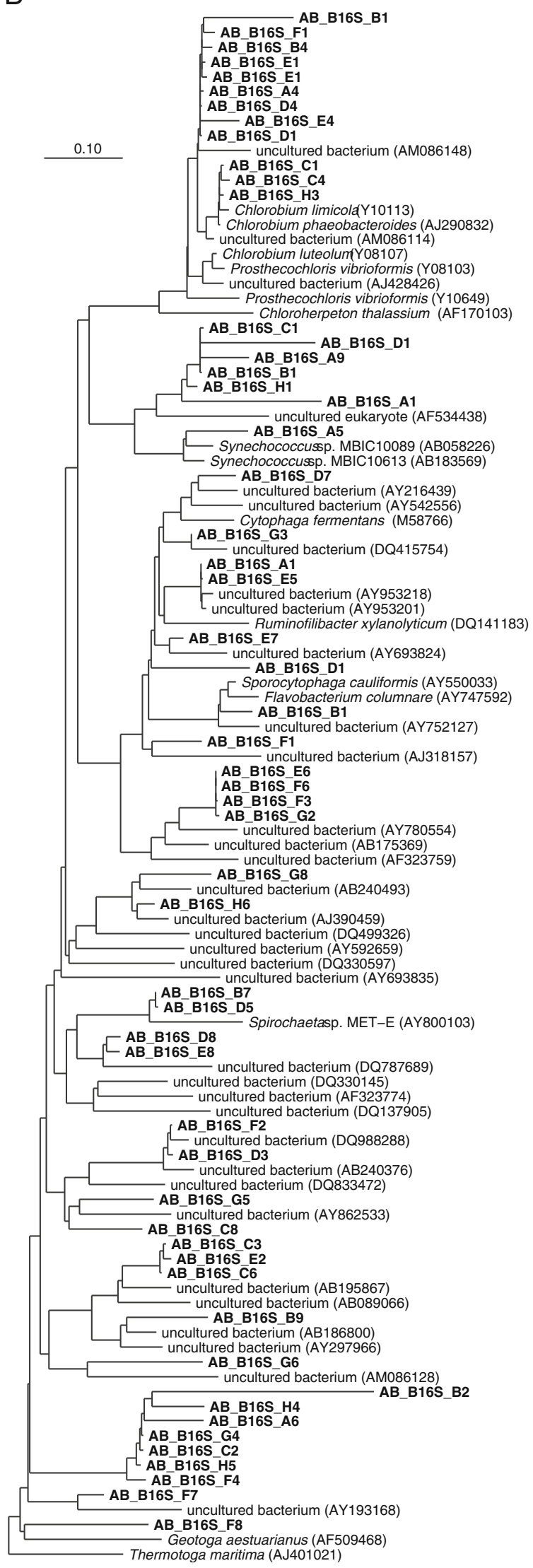

Fig. 1 (continued) enzyme can be found in both groups; the use of the aprA gene allowed the concomitant identification of both SRB and photosynthetic SOB within the WSP. Twenty-four of the sequenced aprA bands were affiliated with sulfatereducing bacteria belonging to the Deltaproteobacteria. Representatives of the sulfate-reducing bacteria community indeed were assigned to the Desulfobacteraceae family. The sequence of band $A_{1}$ had a high similarity of $99 \%$ with the apr A sequence of $D$. postgatei. The closest relative for the sequences $\mathrm{D}_{6}$ and $\mathrm{A}_{8}$ was Desulfonema ishimotonii (95\%). The sequences corresponding to DGGE bands $\mathrm{A}_{4}, \mathrm{~F}_{10}, \mathrm{C}_{1}$, $\mathrm{B}_{8}$, and $\mathrm{C}_{8}$ belonged to representatives of the Desulfobulbus genus. Sequence analysis showed that bands $\mathrm{A}_{4}, \mathrm{~B}_{8}$, and $\mathrm{F}_{10}$ had 95\% similarity with Desulfobulbus sp. DSM 2033, while band C sequence had $89 \%$ similarity with $D$. propionicus. The closest relatives for bands $\mathrm{A}_{9}$ and $\mathrm{D}_{5}$ were Syntrophobacter wolinii (87\%) and Desulfomonile tiedjei (93\%), respectively (Syntrophaceae family). Most of the analyzed aprA gene sequences (58\%) were affiliated with Desulfomicrobium baculatum with a similarity of $97 \%$ (DGGE bands $A_{11}$ and $G_{9}$ ). No spore-forming SRB neither sulfur-oxidizing bacteria aprA-related sequences were founded. Two aprA gene-related sequences $\left(\mathrm{G}_{6}\right.$ and $\left.\mathrm{F}_{8}\right)$ were affiliated to Gammaproteobacterial Thiodictyon, a phototrophic sulfur-oxidizing bacterium of the Chromatiaceae family.

\section{DGGE analysis of pufM gene fragments}

Phylogenetic analysis of the puf $\mathrm{M}$ sequences revealed the presence of members belonging to three different photosynthetic bacterial groups, the PSB, the PNSB, and the aerobic anoxygenic phototrophic bacteria (AAPs). A total of 17 puf $\mathrm{M}$ band sequences belonged to the purple sulfur bacteria and in particular to the family Chromatiaceae. The sequences corresponding to bands $\mathrm{E}_{4}, \mathrm{~B}_{10}$, and $\mathrm{D}_{7}$ showed a $96 \%$ and $89 \%$ similarity to the sequence of Thiorhodococcus drewsii, respectively. DGGE bands $\mathrm{C}_{1}$ and $\mathrm{D}_{8}$ had a $90 \%$ and $88 \%$ sequences similarity with Thiocystis violacea and band $\mathrm{A}_{1}$ had a high level of similarity (99\%) with Allochromatium phaeobacterium. The closest relative for $\mathrm{A}_{6}$ and $\mathrm{E}_{6}$ band sequences was Allochromatium vinosum (97\% similarity). Five sequences were affiliated to members of genus Thiocapsa with different levels of similarity. The sequences corresponding to bands $\mathrm{C}_{4}, \mathrm{C}_{7}$, and $\mathrm{F}_{5}$ showed a $91 \%, 93 \%$, and $95 \%$ similarity to Thiocapsa sp. MTV2IF083, respectively. Bands $\mathrm{D}_{4}$ and $\mathrm{G}_{5}$ sequences had $96 \%$ similarity with Thiocapsa sp. MTRDDF078 and Thiocapsa sp. MTWDM010, respectively. The closest relative to $\mathrm{E}_{9}$ sequence was the marine bacteria Marichromatium indicum ( $92 \%$ similarity).

The PufM gene-related sequences of bands $\mathrm{B}_{2}, \mathrm{D}_{8}, \mathrm{D}_{9}$, $\mathrm{C}_{3}, \mathrm{C}_{10}, \mathrm{~B}_{10}$, and $\mathrm{D}_{7}$ were clustered with members of the 
Fig. 1 (continued)
C

1-DSRbF

Desulfobacter postgatei (AF418198)

Desulfobacter curvatus (AF418199)

Desulfobacter latus (U58124)

Desulfobacter vibrioformis (AJ250472)

Desulfobacula toluolica (AJ457136)

Desulfobacula phenolica (AF551758)

Desulfospira joergensenii (AF551759)

(AF418182)

30-DSRbF

33-DSRbF

Desulfotignum phosphitoxidans (AF420283)

$34-\mathrm{DSRbF}$
$-35-\mathrm{DSR} F$

37-DSR-DSR

37-DSRbF

Desulfobotulus sapovorans (U58120)

Desulfofaba gelida (AF334593)

5-DSRbF

8-DSRbF

13-DS-DSRb

7-DSRbF

Desulfosarcina cetonium (AF420282)

Desulfosarcina cetonium (AF420282)

Desulfococcus multivorans (AJ277107)
Desulfococcus multivorans (U58126, U58127)

Desulfonema ishimotonii (AY626030)

Desulfobacterium oleovorans (AF418201)

Candidatus Desulfococcus oleovorans (NZ_AAWN01000034) 15-DSRbF

20-DSR

17-DSRbF

Desulfovibrionales group

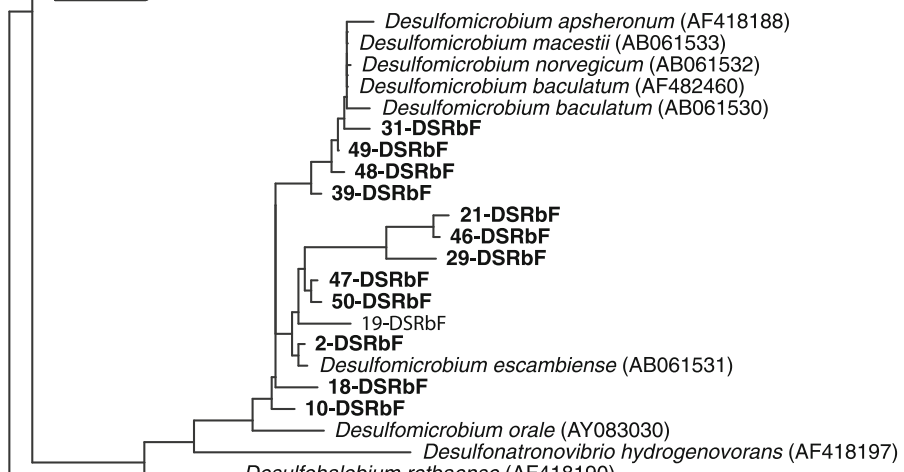

- Desulfohalobium retbaense (AF418190)

41-DSRbF

45-DSRbF

3-DS-DSR

Desulfobulbus elongatus (AF418202)

Desulfobulbus propionicus (AF218452)

Desulfobulbus rhabdoformis (AJ250473)

24-DSRbF

40-DSRbF

Desulfotalea arctica (AY626032)

- Desulfotalea psychrophila (NC_006138)

Desulforhopalus singaporensis (AF418196)

Desulfobulbus sp. (AF337902)

$\mathrm{F}$

Desulfofustis glycolicus (AF418191)

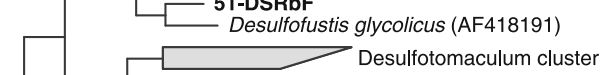

Desulfobacterium anilini (AF482455)

Group containing Thermodesulfobacterium and others

Group containing Desulforhabdus and others

Desulfobacca acetoxidans (AF482453)

Desulfoarculus baarsii (AF334600)

Desulfotomaculum cluster II

Group containing Desulfitobacterium, Desulfosporosinus and others

7 Thermodesulfovibrio cluster

Pelotomaculum sp. MGP (AB154391)

Archaeoglobus cluster

Sulfur oxidizing bacteria group 
Fig. 1 (continued)

$\mathrm{D}$

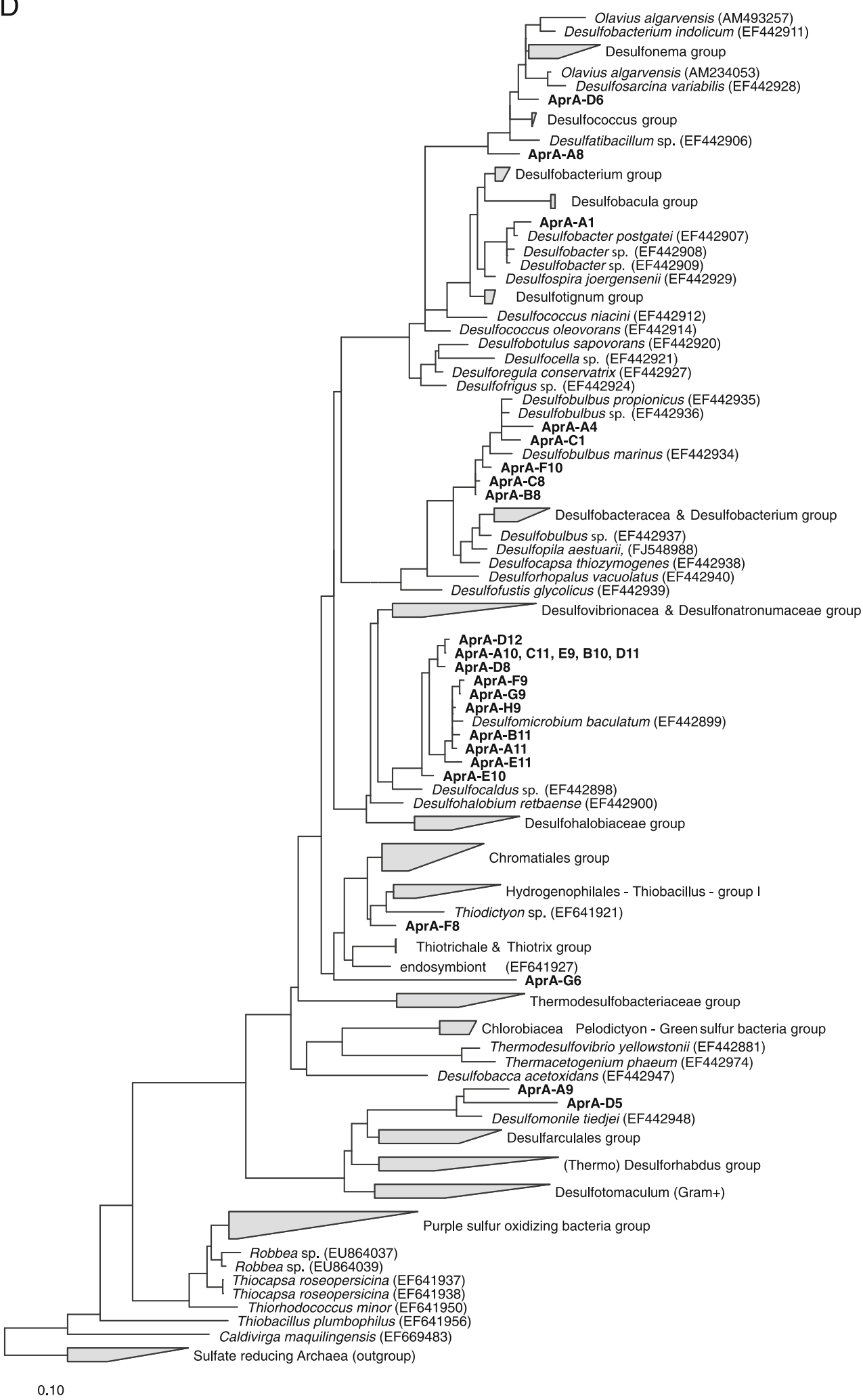

genus Rubrivivax and Rhodoferax of Betaproteobacteria. Sequences of bands $\left(A_{2}, A_{3}, C_{1}, G_{3}\right.$, and $\left.D_{6}\right)$ were affiliated to the phototrophic purple non-sulfur Phaeospirillum genus of the Rhodospirillales family, while those of bands
$\left(\mathrm{D}_{11}, \mathrm{H}_{11}, \mathrm{~B}_{12}, \mathrm{E}_{12}, \mathrm{~B}_{8}\right.$, and $\mathrm{D}_{5}$ ) were affiliated to the photosynthetic purple non-sulfur bacteria Rhodobaca bogoriensis of Alphaproteobacteria. The PNSB were represented also by three different families: Bradyrhizobiaceae, 
Fig. 1 (continued)

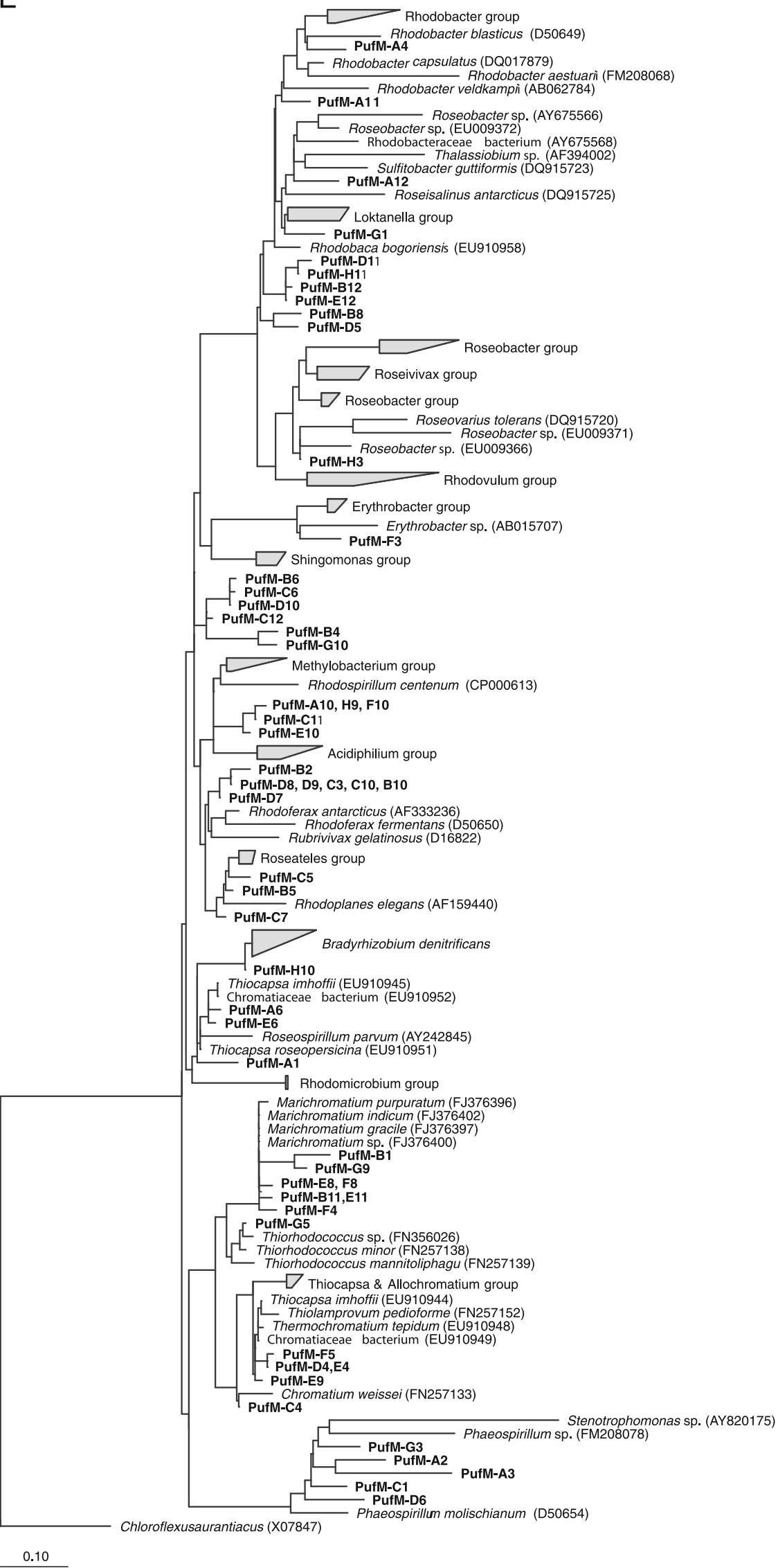


Rhodobacteraceae, and Rhodospirillaceae. Three DGGE bands, $\mathrm{D}_{5}, \mathrm{~A}_{4}$, and $\mathrm{A}_{11}$, had similarities of $98 \%, 88 \%$, and $87 \%$ with the sequences of Rhodobacter sphaeroides and Rhodobacter blasticus, respectively, while the closest relatives for the sequences of bands $\mathrm{H}_{10}, \mathrm{~A}_{2}$, and $\mathrm{G}_{1}$ were Rhodopseudomonas sp. (88\%), Rhodospirillum centenum (87\%), and Rhodobacteraceae bacterium (90\%), respectively.

Representatives of the aerobic photosynthetic bacteria were identified and were assigned to three different families within Alphaproteobacteria: Erythrobacteraceae, Rhodobacteraceae, and Acetobacteraceae. The sequence corresponding to band $\mathrm{F}_{3}$ showed $96 \%$ similarity to the sequence of Erythromicrobium sp. Sequences corresponding to bands $\mathrm{H}_{3}$ and $\mathrm{B}_{8}$ had similarities of $90 \%$ and $94 \%$ with pufM sequences of a Roseobacter sp. and Roseococcus thiosulfatophilus, respectively.

\section{Discussion}

Performance of the wastewater stabilization pond system

Wastewater stabilization ponds are without doubt the most important method of wastewater treatment in developing countries where sufficient space is available and where the temperature is most favorable for their operation. The deepest ponds (the anaerobic and facultative ponds) generally stratify between March and September due to their small size and as a result of warm climatic conditions and the absence of artificial aeration (Abis and Mara 2006). During this period, the sulfate reduction process becomes the dominant process in the sediments of these ponds and is stimulated by the increase in temperature. All ponds become fully anoxic and this was indicated by the black coloration of elemental sulfur deposits from the oxidation of hydrogen sulfide (Table 2). The stabilization ponds failure is reflected by the changes in the pond biology through the reduction of the wastewater treatment efficiency and the change of the WSP pigmentation. The hydrogen sulfide produced spontaneously reduces oxygen expanding the anaerobic zone throughout the water column within the facultative pond and may even diffuse into the maturation ponds. Sulfide toxicity affects algal growth (Konig et al. 1987) and stimulates the prevalence of anoxic conditions and the purple photosynthetic bacteria become visible at the surface (Lai and Lam 1997).

Analysis of the total bacterial community

So far, most studies have focused on the removal of pathogens and only a few studies have focused on the characterization of microbial communities in wastewater stabilization ponds (Shammas et al. 2009). The major bacterial groups (i.e., Proteobacteria, Chlorobi, Bacteroidetes, and Acidobacteria) found in this study have been previously found in other wastewater treatment systems, such as activated sludge, aerated lagoons, and sewage treatment plants (Malik et al. 2008; Moura et al. 2009). The bacteria detected were related to known organisms involved in the degradation of diverse pollutants, suggesting a similar role of these microorganisms within the wastewater stabilization pond system. The 16S rRNA gene sequences affiliated with the Proteobacteria, Chlorobi, Bacteroidetes, and Cyanobacteria phyla were the most frequently retrieved. A similar bacterial community composition has been previously described from a wastewater treatment plant (Wagner et al. 1993; Wagner and Loy 2002). The predominance of the Proteobacteria was in accordance with previous results obtained by Boon et al. (2002) and Ding et al. (2010).

Representatives of the Proteobacteria classes were most abundantly present within the WSP; this result was in accordance with those obtained by Xia et al. (2010) who reported the predominance of the Proteobacteria within five biological wastewater treatment reactors. This bacterial phylum is known to flourish in eutrophic ponds and is responsible for the removal of the organic matters from municipal wastewater (Wagner et al. 2002). The distribution of the different classes of Proteobacteria varies according to the type of wastewater treated (Arroyo et al. 2010). In contrast, while the Alphaproteobacteria tend to dominate within activated sludge (LaPara et al. 2000), the proteobacterial community in our system was dominated by members of Betaproteobacteria and Gammaproteobacteria.

\section{$\mathrm{SRB}$ in wastewater treatment systems}

SRB are present in wastewater treatment plants (Muyzer and Stams 2008) treating domestic (Baena et al. 1998) and industrial (Ben-Dov et al. 2007) wastewater. Sulfate reducers play a significant role in the anaerobic biomineralization pathways, especially in wastewater treatment systems (Oude Elferink et al. 1994) where sulfate reduction can be the dominant terminal electron-accepting process and can even account for up to $50 \%$ of mineralization of organic matter in wastewater.

$16 \mathrm{~S}$ rRNA, aprA-, and $d s r \mathrm{~B}-$ genes analysis revealed the presence of the sulfate reducers within all water and sediment samples. The SRB community was phylogenetically diverse and all representatives are Gram-negative mesophilic SRB of the Deltaproteobacteria class. Representatives of this bacterial guild belonged to the family of Desulfobacteraceae (Desulfobacter, Desulfotignum, Desulfobotulus, and Desulfococcus), the family of Desulfobulbaceae (Desulfobulbus and Desulfofustis), the family of Desulfomicrobiaceae (Desulfomicrobium), the family of 
Syntrophaceae (Desulfomonile), and the family of Syntrophobacteraceae (Syntrophobacter). Most of these bacterial genera have been previously isolated and/or identified within wastewater treatment systems (Mohanakrishnan et al. 2011; Raskin et al. 1995). Similar sulfate-reducing bacteria community composition has been previously reported from wastewater environments, such as upflow anaerobic sludge bed wastewater treatment reactors (UASB) (Dar et al. 2005) or wastewater biofilm (Okabe et al. 1999).

The SRB are divided into two broad subdivisions that belie physiological and ecological roles of the two groups: complete and incomplete oxidizers. Complete oxidizers typically utilize a broader range of substrates than incomplete oxidizers and may be considered as generalists compared with the more specialist incomplete oxidizers. Representatives of both groups were identified within the WSP, complete oxidizers were represented by species of the genera Desulfobacter, Desulfococcus, Desulfonema, Desulfosarcina, and Desulfomonile (Rabus et al. 2006), while the incomplete oxidizers include representatives of the genera Desulfovibrio, Desulfomicrobium, and Desulfobulbus (Madigan and Martinko 2006). Incomplete oxidizers are present in the anoxic pond, while the complete oxidizers may be located in the following facultative and maturation ponds. Indeed the growth kinetics for incomplete oxidizers is generally faster than the complete oxidizers. However, the former are less versatile regarding their nutritional requirements (Widdel 1988); in addition, complete oxidizers have the ability to oxidize the organic compound to carbon dioxide, and incomplete oxidizers carry out the incomplete oxidation of the organic compound to acetate and $\mathrm{CO}_{2}$ which subsequently can be used by complete oxidizers further in the WSP system.

\section{Analysis of SOB-like sequences}

Based on the 16S rRNA, aprA, and pufM gene analysis, the phylogenetic complexity of SOPs in the WSP consisted of putative strains of the GSB (Chlorobi), the Gammaproteobacterial PSB and the Alphaproteobacterial PNSB; all these bacteria have been shown to be able to oxidize reduced sulfur compounds (Brune 1995).

Many pufM sequences were related to the purple nonsulfur bacteria; these bacteria preferentially grow photoheterotrophically under anaerobic conditions in the light by using various organic substrates. Nevertheless and contrary to the misleading nomenclature, many of these bacteria are also able to use sulfur compounds as a source of electrons (Imhoff et al. 2005). It is now well established that a number of purple non-sulfur bacteria are able to grow photolithoautotrophically with reduced sulfur compounds such as Rhodobacter, Rhodopseudomonas, Rhodoferax, and Rubrivivax, which can use hydrogen, sulfide, thiosulfate, or ferrous iron as electron donors to support their anoxic, phototrophic growth (Kopriva et al 2008).

In contrast to results generated by the pufM DGGE-based approach, only two aprA sequences were affiliated to Thiodictyon, a sulfur-oxidizing bacterium which is an obligate and strictly anaerobic phototroph. This difference between the $p u f \mathrm{M}$ - and the aprA-based approaches may be explained by the limited phylogenetic distribution of APS reductaseencoding genes among phototrophic bacteria, unlike the sox gene which is found in all Chromatiaceae (Meyer et al. 2007). Indeed apr AB gene distribution is restricted in Chlorobiaceae to members of sub-clusters 3 and $4 \mathrm{~b}$, to some species of Chromatiaceae, while absent throughout the Rhodospirillaceae and Ectothiorhodospiraceae families (Meyer and Kuever 2007b), thus limiting the utility of using apr genes to the survey of anoxygenic phototrophic SOB. The pufM gene universally distributed among all purple anoxygenic photosynthetic (Tank et al. 2009), which may explain the high diversity of the purple anoxygenic phototrophic bacteria revealed in comparison with the former genes ( $d s r \mathrm{~B}$ and $a p r \mathrm{~A})$. This gene may constitute a better target to circumvent this limitation but this gene is not directly linked to the sulfide oxidation process and this may explain why many puf M-related sequences belonged to bacteria which were not able to use reduced sulfur compounds (i.e., PNSB). The primer set pufM557F-pufM750R used within this study allows the detection of both PSB and PNSB. It should be remembered that this primer set might also amplify pufM gene fragment of aerobic phototrophs (Shimada 1995) and the green non-sulfur bacterium Chloroflexus aurantiacus, which performs a purple bacterial-type reaction (Achenbach et al. 2001), but in our case C. aurantiacus was not detected within the investigated wastewater stabilization ponds.

Another important bacterial sulfur-oxidizing community was identified within the stabilization plant. A total of $15.5 \%$ of the retrieved $16 \mathrm{~S}$ rRNA gene sequences were assignd to the GSB phylum. These bacteria carry out anoxygenic photosynthesis with reduced sulfur compounds such as sulfide and elemental sulfur and, for some species, thiosulfate as the electron donor for photoautotrophic growth (Frigaard and Dahl 2009). Some GSB also use hydrogen and ferrous iron as the electron donors. GSB are obligately anaerobic and obligately photoautotrophic, and they form a phylogenetically and physiologically distinct group (Imhoff 2008). They are commonly found in anoxic and sulfide-rich freshwater and estuarine environments as well as in wastewater treatment plants (Siefert et al. 1978) where they may form green or brown bloom depending on their lightharvesting pigments (bacteriochlorophyll $c$ or $d$ or $e$ ).

While the ecology of GSB and PSB is to some extent similar (Overmann 2008), their oxidative sulfur metabolism probably shares many characteristics as well (Brune 1995). 
GSB have a high affinity for sulfide, which is usually the preferred substrate even if other sulfur substrates are available (Brune 1995). The GSB affinity for sulfide is one order of magnitude higher than that of Chromatiaceae (Van Gemerden and Mas 1995). In addition, GSB are capable of using significantly lower light intensities for photosynthetic growth. Consequently, green sulfur bacteria thrive below layers of Chromatiaceae in close association with the sulfate-reducing bacteria.

\section{Congruency of phylogenetic results}

Congruent phylogenetic results were obtained by applying apr $\mathrm{A}$ and $d s r \mathrm{~B}$ genes for the characterization of the SRB community with exception concerning $D$. tiedjei. Both functional marker genes allowed the detection of representatives belonging to the Desulfobulbaceae, Desulfobacteraceae, and Desulfomicrobiaceae families. SRB representatives of the Desulfococcus/Desulfosarcina cluster, Desulfobacter, Desulfobulbus, and Desulfomicrobium were found in both $d s r \mathrm{~B}$ and $a p r \mathrm{~A}$ data.

The sulfate-reducing bacterium $D$. tiedjei was only detected by aprA-based DGGE approach. This bacterial species is a lateral gene transfer-affected member of the Syntrophobacteraceae family, the reclassification of which through Deltaproteobacteria is proposed based on the phylogenetic relationship of the xenologous aprBA genes (Meyer and Kuever 2007a). While all sequences retrieved with the $d s r$ and apr primers were dsr and apr sequences, only one of the $16 \mathrm{~S}$ rRNA sequences was clearly related to sulfate-reducing bacteria; this difference may be attributed to the fact that these functional genes are directly linked to the dissimilatory sulfate reduction and sulfur oxidation processes whereas the ecophysiology and the metabolic function of the microorganisms characterized only by the $16 \mathrm{~S}$ rRNA sequence remain largely unknown. Furthermore, the phylogenetic specificity of the $d s r \mathrm{~B}$ and $a p r \mathrm{~A}$ primer sets was superior to the specificity of the $16 \mathrm{~S}$ rRNA primer set used herein for revealing the SRB community, while both primers used in this study target all known groups of sulfatereducing bacteria (Wagner et al. 1998). The differences observed in resolving the diversity of the phototrophic SOB community between aprA and puf $\mathrm{M}$ genes may be attributed to the limited distribution of aprA gene among the photosynthetic sulfur-oxidizing bacterial community. So, the use of different genes to characterize microbial communities as has been performed in this study nicely complements the limitations and biases of the different individual genes and will hence give a good overview of the different members that are present in our WSP system.

The data recovered from the $16 \mathrm{~S} r \mathrm{rNA}, d s r \mathrm{~B}, \operatorname{apr} \mathrm{A}$, and puf $\mathrm{M}$ genes were complementary. The $16 \mathrm{~S}$ rRNA genes allowed the determination of the major bacterial groups independently on their physiological or metabolic capacities, while $d s r \mathrm{~B}$ and $a p r \mathrm{~A}$ genes were used to get insight on the sulfur metabolism pathways. The aprA gene allowed the identification of the SOB and SRB communities concomitantly since the primer used targets the same conserved gene region (Meyer and Kuever 2007c). In contrary, the primer designed on $d s r \mathrm{~B}$ is not specific for $\mathrm{SOB}$ analysis and all $d s r \mathrm{~B}$ sequences belonged to SRB. Despite that the core molecular unit $d s r \mathrm{ABCNMKJOP}$ is common to both sulfur oxidizers and sulfate reducers, only $d s r \mathrm{EFH}$ and $d s r \mathrm{~L}$ are specific for SOB (Grimm et al. 2008). The pufM genewhile not directly involved in sulfur oxidation processallowed the detection of all anoxygenic purple phototrophic bacteria, most representatives of which are able to oxidize sulfide. The use of functional genes of SOB such as sox and $s q r$ genes will offer a better view of the sulfide oxidation pathways among this photosynthetic bacterial community.

The PCR-DGGE approach has proven efficient in studying the microbial ecology of wastewater treatment systems as reviewed by Sanz and Köchling (2007). Although the approach provides new insights into the genetic and metabolic composition of these ecosystems, limitations may exist, such as the difficulty in band isolation and the overestimation of sequence heterogeneity in single DGGE bands (Zhang et al. 2005). In addition, the limited DNA sequence information obtained from these relatively short fragments (i.e., pufM, 229 bp; aprA, 400 bp) can lessen the specificity of the phylogenetic identification. Apart from limitations attributed to DGGE, general biases, such as DNA extraction efficiency, inhibition of PCR, differential amplification, and the incidence of artifact bands due to excessive amplification cycles (Moura et al. 2009), have to be taken into account as well.

\section{Ecological significance of sulfur bacteria in WSP systems}

In such aquatic ecosystems as WSP, a complex microbial consortium with interacting and complementary metabolic processes often exist where major metabolic bacterial groups, such as methanogens, nitrifiers, SRB, sulfideoxidizing bacteria, and fermenters, can coexist and dominate when the conditions favor their metabolic processes. Based on the 16S rRNA gene database, the dominant metabolism is not linked to sulfate reduction and neither to sulfide oxidation; consequently, fermentation and syntrophic pathways might be important but this cannot be discerned with the 16S rRNA gene results. Chlorobi $(15.5 \%)$ was one of the most dominant bacterial groups identified in this study. Representatives of this phylum share a large set of orthologues to accomplish the demanding task of photosynthesis and sulfur oxidation. They utilize various combinations of sulfide, elemental sulfur, and thiosulfate and sometimes also ferrous iron and hydrogen (Goh et al. 2009). 
Since the sulfur cycle involves the presence of SRB and sulfide-oxidizing bacteria, the identification of Chlorobi, PSB, and PNSB in the WSP suggest the presence of sulfate-reducing bacteria. This was confirmed by the detection of both $d s r \mathrm{~B}$ and aprA sequences related to SRB. Due to their strict anaerobic character, SRB identified herein are likely to dominate within the anoxic and the facultative ponds (i.e., in sediments and the deeper water layers) or within anoxic micro-niches rather than in the maturation ponds where they may constitute only a minor component of bacterial community.

The SRB reduce sulfate to sulfide using either hydrogen as an energy source or $\mathrm{CO}_{2}$, acetate, lactate, and other shortchain carboxylic acids as carbon and energy sources. In this study, two SRB communities were distinguished: the SRB with respiratory type of metabolism such as Desulfobacter, Desulfonema, and Desulfomonile and SRB community with both respiratory and fermentative type of metabolism like Desulfotignum, Desulfomicrobium, and Desulfobulbus. The sulfide generated by the SRB activity constitutes a major electron donor for the phototrophic purple sulfur bacteria and may be also used by purple non-sulfur bacteria identified herein such as Rhodopseudomonas, Rhodobacter, and Rhodospirillum. Sulfide oxidation to sulfate would prevent accumulation of sulfide in the wastewater stabilization ponds. The sulfur-oxidizing microbial community within the wastewater stabilization plant is complex and it was suggested to consist of the phototrophic Gammaproteobacteria sulfur-oxidizing representatives, the phototrophic Alphaproteobacteria and Betaproteobacteria SOB (PNSB), and the photoautotrophic sulfur-oxidizing green sulfur bacteria.

The collective data obtained in this study provided insights regarding the composition and the structure of the sulfur microbial community within a wastewater stabilization plant; this may allow a better understanding of the seasonal changes that may affect the microbial community structure especially during the spring and the summer seasons and thus the wastewater treatment's efficiency. Certainly, in pond design, both effluent characteristics and bacterial community should be taken into account and each pond provides the proper environmental conditions needed for bacterial growth, that is why complex bacterial communities should be monitored in order to guarantee the efficiency of the WSP. The relatively high phylogenetic diversity of the anoxygenic photosynthetic purple and green bacteria reflects their predominance among the total bacterial community within the wastewater stabilization plant since they constitute the most prominent group among the sulfuroxidizing bacterial community. The diversity of the purple anoxygenic phototrophic bacteria traduces their ecological role in the wastewater treatment process. These bacteria, stimulated by the degradation of environmental parameters during the warm seasons (spring and summer), flourish by forming red-water and may contribute also to biological balance restoration. Further studies on these bacteria can contribute to a better understanding of their roles in these ecosystems.

Acknowledgments We are grateful to the Tunisian Ministry of High Education Scientific Research and Technology for financial support.

Open Access This article is distributed under the terms of the Creative Commons Attribution License which permits any use, distribution, and reproduction in any medium, provided the original author(s) and the source are credited.

\section{References}

Abis KL, Mara DD (2006) Temperature measurement and stratification in facultative waste stabilization ponds in the UK climate. Environ Monit Assess 114:35-47

Achenbach LA, Carey J, Madigan MT (2001) Photosynthetic and phylogenetic primers for detection of anoxygenic phototrophs in natural environments. Appl Environ Microbiol 6:2922-2926

Anceno AJ, Ozaki M, Dang YND, Chuluun B, Shipin OV (2007) Canal networks as extended waste stabilization ponds: fate of pathogens in constructed waterways in Pathumthani province, Thailand. Water Sci Technol 55:143-156

APHA-American Public Health Association (1995) Standard methods for the examination of water and wastewater, 19th edn. American Public Health Association, Washington, DC

Arroyo P, Gemma A, Ivan B, Patricia M, de Estanislao LC, Luis E, de Saenez M (2010) Comparative analysis of the composition of bacterial communities from two constructed wetlands for municipal and swine wastewater treatment. J Water Health 8:147-157

Asano R, Sasaki T, Nakai Y (2007) Isolation and characterization of sulphur oxidizing bacteria from cattle manure compost. Anim Sci J 78:330-333

Baena S, Fardeau ML, Labat M, Ollivier B, Garcia JL, Patel BKC (1998) Desulfovibrio aminophilus sp. nov., a novel amino acid degrading and sulphate reducing bacterium from an anaerobic dairy wastewater lagoon. J. Syst Appl Microbiol 21:498-504

Belila A, Gtari M, Ghrabi A, Hassen A (2009) Purple anoxygenic phototrophic bacteria distribution in Tunisian wastewater stabilization plant exhibiting red water phenomenon. Ann Microbiol 59:399-408

Ben-Dov E, Brenner A, Kushmaro A (2007) Quantification of sulfatereducing bacteria in industrial wastewater, by real-time polymerase chain reaction (PCR) using $d s r \mathrm{~A}$ and apsA genes. Microb Ecol $54: 439-451$

Boon N, De Windt W, Verstraete W, Top EM (2002) Evaluation of nested PCR-DGGE (denaturing gradient gel electrophoresis) with group-specific $16 \mathrm{~S}$ rDNA primers for the analysis of bacterial communities from different wastewater treatment plants. FEMS Microbiol Ecol 39:101-112

Brune DC (1995) Sulfur compounds as photosynthetic electron donors. In: Blankenship RE, Madigan MT, Bauer CE (eds) Anoxygenic photosynthetic bacteria. Kluwer Academic, Dordrecht, The Netherlands, pp 847-870

Corson GE, Nagashima KVP, Matsuura K, Sakuragi Y, Wettasinghe R, Qin H, Allen R, Knaff DB (1999) Genes encoding light harvesting and reaction center proteins from Chromatium vinosum. Photosynth Res 59:39-52 
Cravo-Laureau C, Matheron R, Cayol J-L, Joulian C, Hirschler-Réa A (2004) Desulfatibacillum aliphaticivorans gen. nov., sp. nov., an n-alkane- and n-alkene-degrading sulfate-reducing bacterium. Int J Syst Evol Microbiol 54:77-83

Curtis TP, Mara DD, Dixo NGH, Silva SA (1994) Light penetration in waste stabilization ponds. Water Res 28:1031-1038

Dahl C, Prange A (2006) Bacterial sulfur globules: occurrence, structure, and metabolism. In: Shively JM (ed) Bacterial inclusions (microbiological monographs (1)). Springer, New York, pp 21-51

Dar SA, Kuenen JG, Muyzer G (2005) Nested PCR denaturing gradient gel electrophoresis approach to determine the diversity of sulfatereducing bacteria in complex microbial communities. Appl Environ Microbiol 71:2325-2330

Dar SA, Yao L, Van Dongen U, Kuenen JG, Muyzer G (2007) Analysis of diversity and activity of sulfate reducing bacterial communities in sulfidogenic bioreactors using $16 \mathrm{~S}$ rRNA and $d s r \mathrm{~B}$ genes as molecular markers. Appl Environ Microbiol 73:594-604

Devereux R, Delaney M, Widdel F, Stahl DA (1989) Natural relationships among sulfate-reducing eubacteria. J Bacteriol 171:66896695

Ding L, Zhou Q, Wang L, Zhang Q (2010) Dynamics of bacterial community structure in a fullscale wastewater treatment plant with anoxic-oxic configuration using 16S rDNA PCR-DGGE fingerprints. Afr J Biotechnol 10:589-600

Frigaard NU, Dahl C (2009) Sulfur metabolism in phototrophic sulfur bacteria. Adv Microb Physiol 54:103-200

Geets J, Borremans B, Diels L, Springael D, Vangronsveld J, Van der Lelied D, Vanbroekhoven K (2006) DsrB gene-based DGGE for community and diversity surveys of sulfate-reducing bacteria. $\mathrm{J}$ Microbiol Meth 66:194-205

Ghosh W, Dam B (2009) Biochemistry and molecular biology of lithotrophic sulfur oxidation by taxonomically and ecologically diverse bacteria and Archaea. FEMS Microbiol Rev 33:999-1043

Goh SHM, Mabbett AN, Welch JP, Hall SJ, McEwan AG (2009) Molecular ecology of a facultative swine waste lagoon. Lett Appl Microbiol 48:486-492

Grimm F, Franz B, Dahl C (2008) Thiosulfate and sulfur oxidation in purple sulfur bacteria. In: Microbial sulfur metabolism. Springer, Berlin, pp 101-116

Imhoff JF (2005) The anoxygenic phototrophic purple bacteria. In: Boone, Castenholz and Garrity (ed), Bergey's Manual of Systematic Bacteriology, 2nd edn, Vol 1, Springer-Verlag, New York, pp 631-637

Imhoff JF (2008) Systematics of anoxygenic phototrophic bacteria. In: Hell R, Dahl C, Knaff DB, Leustek T (eds) Sulfur metabolism in phototrophic organisms. Springer, The Netherlands, pp 269-287

Karr EA, Sattley WM, Jung DO, Madigan MT, Achenbach LA (2003) Remarkable diversity of phototrophic purple bacteria in a permanently frozen Antarctic lake. Appl Environ Microbiol 69:4910 4914

Konig A, Pearson HW, Silva SA (1987) Ammonia toxicity to algal growth in waste stabilization ponds. Water Sci Technol 19:115-122

Kopriva S, Patron N, Leustek T, Keeling P (2008) Phylogenetic analysis of sulfate assimilation and cysteine biosynthesis in phototrophic organisms. In: Hell R, Leustek T, Dahl C, Knaff D (eds) Advances in photosynthesis and respiration, vol 27, sulfur metabolism in phototrophic organisms. Springer, Dordrecht, pp 33-60

Kubo K, Knittel K, Amann R, Fukui M, Matsuura K (2011) Sulfurmetabolizing bacterial populations in microbial mats of the Nakabusa hot spring. Syst Appl Microbiol 34:293-302

Lai PCC, Lam PKS (1997) Major pathways for nitrogen removal in waste water stabilization ponds. Water Air Soil Pollut 94:125-136

LaPara TM, Nakatsu CH, Pantea L, Allemann JE (2000) Phylogenetic analysis of bacterial communities in mesophilic and thermophilic bioreactors treating pharmaceutical wastewater. Appl Environ Microbiol 66:3951-3959
Lücker S, Steger D, Kjeldsen KU, MacGregor BJ, Wagner M, Loy A (2007) Improved 16S rRNA targeted probe set for analysis of sulfate-reducing bacteria by fluorescence in situ hybridization. J Microbiol Meth 69:523-528

Ludwig W, Strunk O, Westram R, Richter L, Meier H, Yadhukumar A, Buchner T, Lai S, Steppi G, Jobb W, Förster I, Brettske S, Gerber AW, Ginhart O, Gross S, Grumann S, Hermann R, Jost A, König T, Liss R, Lüssman M, May B, Nonhoff B, Reichel R, Strehlow A, Stamatakis N, Stuckmann A, Vilbig M, Lenke T, Ludwig AB, Schleifer K-H (2004) ARB: a software environment for sequence data. Nucleic Acids Res 32:1363-1371

Madigan MT (1995) Microbiology of nitrogen fixation in photosynthetic bacteria. In: Blankenship RE, Madigan MT, Bauer CE (eds) Anoxygenic photosynthetic bacteria. Kluwer Academic, Dordrecht, pp 915-928

Madigan MT, Martinko JM (2006) Brock biology of microorganisms, 11th edn. Prentice Hall, Upper Saddle River, NJ

Malik S, Beer M, Megharaj M, Naidu R (2008) The use of molecular techniques to characterize the microbial communities in contaminated soil and water. Environ Int 34:265-276

Mara DD (2008) Waste stabilization ponds: a highly appropriate wastewater treatment technology for Mediterranean countries. In: Al Baz I, Otterpohl R, Wendland C (eds) Efficient management of wastewater: its treatment and reuse in water-scarce countries. Springer, Berlin, pp 113-123

Meyer B, Kuever J (2007a) Phylogeny of the alpha and beta subunits of the dissimilatory adenosine-5'-phosphosulfate (APS) reductase from sulfate-reducing prokaryotes - origin and evolution of the dissimilatory sulfate-reduction pathway. Microbiology 153:2026-2044

Meyer B, Kuever J (2007b) Molecular analysis of the distribution and phylogeny of dissimilatory adenosine-5'-phosphosulfate reductase-encoding genes (aprAB) among sulfur-oxidizing prokaryotes. Microbiology 153:3478-3498

Meyer B, Kuever J (2007c) Molecular analysis of the diversity of sulfate-reducing and sulfur-oxidizing prokaryotes in the environment, using aprA as functional marker gene. Appl Environ Microbiol 73:7664-7679

Meyer B, Kuever J (2008) Phylogenetic diversity and spatial distribution of the microbial community associated with the Caribbean deep-water sponge Polymastia cf. corticata by $16 \mathrm{~S}$ rRNA, aprA, and $a m o A$ gene analysis. Microb Ecol 56:306-321

Meyer B, Imhoff JF, Kuever J (2007) Molecular analysis of the distribution and phylogeny of the soxB gene among sulphuroxidizing bacteria-evolution of the Sox sulphur oxidation enzyme system. Environ Microbiol 9:2957-2977

Miletto M, Bodelier PLE, Laanbroek HJ (2007) Improved PCRDGGE for high resolution diversity screening of complex sulfate-reducing prokaryotic communities in soil and sediments. J Microbiol Meth 70:103-111

Mohanakrishnan J, Kofoed MV, Barr J, Yuan Z, Schramm A, Meyer RL (2011) Dynamic microbial response of sulfidogenic wastewater biofilm to nitrate. Appl Microbiol Biotechnol 91:1647-1657

Moura A, Tacão M, Henriques I, Dias J, Ferreira P, Correia A (2009) Characterization of bacterial diversity in two aerated lagoons of a wastewater treatment plant using PCR-DGGE analysis. Microbiol Res 164:560-569

Muyzer G, Stams AJM (2008) The ecology and biotechnology of sulphate-reducing bacteria. Nat Rev Microbiol 6:441-454

Muyzer G, Teske A, Wirsen CO, Jannasch HW (1995) Phylogenetic relationships of Thiomicrospira species and their identification in deep-sea hydrothermal vent samples by denaturing gradient gel electrophoresis of $16 \mathrm{~S}$ rDNA fragments. Arch Microbiol 164:165-172

Nair C (1992) Pollution control through water conservation and wastewater reuse in the fish processing industry. Water Sci Technol 22:113-121 
Okabe S, Itoh T, Satoh H, Watanabe Y (1999) Analyses of spatial distributions of sulfate-reducing bacteria and their activity in aerobic wastewater biofilms. Appl Environ Microbiol 65:5107-5116

ONAS (2009) Annual report of the National Office of Sanitation. National Office of Sanitation, Tunisia

Oude Elferink SJWH, Visser A, Hulshoff PLW, Stams AJM (1994) Sulfate reduction in methanogenic bioreactors. FEMS Microbiol Rev 15:119-136

Overmann J (2008) Ecology of phototrophic sulfur bacteria. In: Hell R, Dahl C, Knaff DB, Leustek T (eds) Advances in photosynthesis and respiration. Springer, New York, pp 375-396

Pearson HW (1986) Estimation of chlorophyll $a$ as a measure of algal biomass in waste stabilization ponds. Regional Seminar on Waste Stabilization Pond Research, CEPIS, Lima

Pierson BK, Olson JM (1987) Photosynthetic bacteria. In: Amesz J (ed) Photosynthesis. Elsevier Science, BV, Amsterdam, pp 21-42

Rabus R, Hansen TA, Widdel F (2006) Dissimilatory sulfate and sulfur-reducing. In: Dworkin M, Falkow S, Rosenberg E, Schleifer $\mathrm{KH}$, Stackebrandt E (eds) The prokaryotes, vol. 2, 3rd edn. Springer, New York, pp 659-768

Ranchou-Peyruse A, Herbert R, Caumette P, Guyoneaud R (2006) Comparison of cultivation dependent and molecular methods for studying the diversity of anoxygenic purple phototrophs in sediments of a eutrophic brackish lagoon. Environ Microbiol 8:1590-1599

Raskin L, Zheng D, Griffin ME, Stroot PG, Misra P (1995) Characterization of microbial communities in anaerobic bioreactors using molecular probes. Antonie Van Leeuwenhoek 68:297-308

Reinoso R, Bécares E (2008) Environmental inactivation of Cryptosporidium parvum oocysts in waste stabilization ponds. Microb Ecol 56:585-592

Sander J, Dahl C (2008) Metabolism of inorganic sulfur compounds in purple bacteria. In: Hunter CN, Daldal F, Thurnauer MC, Beatty JT (eds) The purple phototrophic bacteria. Kluwer Academic, Dordrecht, pp 595-622

Sanz JL, Köchling T (2007) Molecular biology techniques used in wastewater treatment: an overview. Process Biochem 42:119-133

Schäfer H, Muyzer G (2001) Denaturing gradient gel electrophoresis in marine microbial ecology. In: Paul J (ed) Methods in Microbiology, Vol 30, Academic Press, London, pp 425-468

Shammas NK, Wang LK, Wu Z (2009) Wastewater stabilization ponds and lagoons. Biological treatment processes. In: Wang LK, Pereira NC, Hung YT (eds) Biological treatment processes, vol 8. Humana, Totowa, NJ, pp 315-370

Shimada K (1995) Aerobic anoxygenic phototrophs. In: Blankenship RE, Madigan MT, Bauer CE (eds) Anoxygenic photosynthetic bacteria. Kluwer Academic, Dordrecht, pp 105-122

Siefert E, Irgens RL, Pfennig N (1978) Phototrophic purple and green bacteria in a sewage treatment plant. Appl Environ Microbiol $35: 38-44$
Tang K, Baskaran V, Nemati M (2008) Bacteria of the sulphur cycle: an overview of microbiology, biokinetics and their role in petroleum and mining industries. Biochem Eng J 44:73-94

Tank M, Thiel V, Imhoff JF (2009) Phylogenetic relationship of phototrophic purple sulfur bacteria according to $p u f \mathrm{~L}$ and $p u f \mathrm{M}$ genes. Int Microbiol 12:175-185

Tyagi VK, Kazmi AA, Chopra AK (2008) Removal of fecal indicators and pathogens in a waste stabilization pond system treating municipal wastewater in India. Water Environ Res 80:21112117

Van Gemerden H, Mas J (1995) Ecology of phototrophic sulfur bacteria. In: Blankenship RE, Madigan MT, Bauer CE (eds) Anoxygenic photosynthetic bacteria. Advances in photosynthesis, vol 2. Springer, Dordrecht, pp 49-85

Vannini C, Munz G, Mori G, Lubello C, Verni F, Petroni G (2008) Sulphide oxidation to elemental sulfur in a membrane bioreactor: performance and characterization of the selected microbial sulphur-oxidizing community. Syst Appl Microbiol 31:461-473

Veenstra S, Al-Nozaily FA, Alaerts GJ (1995) Purple non-sulfur bacteria and their influence on waste stabilization pond performance in the Yemen Republic. Water Sci Technol 31:141-149

Villanueva J, Grimalt JO, Wit RD, Brendan JK, Maxwell JR (1994) Sources and transformations of chlorophylls and carotenoids in a monomictic sulphate-rich karstic lake environment. Org Geochem 22:739-757

Wagner M, Loy A (2002) Bacterial community composition and function in sewage treatment systems. Curr Opin Biotechnol 13:218-227

Wagner M, Amann R, Lemmer H, Schleifer KH (1993) Probing activated sludge with oligonucleotides specific for proteobacteria: inadequacy of culture-dependent methods for describing microbial community structure. Appl Environ Microbiol 59:1520-1525

Wagner M, Roger AJ, Flax JL, Brusseau GA, Stahl DA (1998) Phylogeny of dissimilatory sulfite reductases supports an early origin of sulfate respiration. J Bacteriol 180:2975-2982

Wagner A, Loy R, Nogueira U, Purkhold LN, Daims H (2002) Microbial community composition and function in wastewater treatment plants. Antonie Van Leeuwenhoek 81:665-680

Widdel F (1988) Microbiology and ecology of sulphate and sulphur reducing bacteria. In: Zehnder AJB (ed) Biology of anaerobic microorganisms. Wiley Interscience, New York, pp 469-586

Xia S, Duan L, Song Y, Li J, Piceno YM, Andersen GL, AlvarezCohen L, Moreno-Andrade I, Huang CL, Hermanowicz SW (2010) Bacterial community structure in geographically distributed biological wastewater treatment reactors. Environ Sci Technol 44:7391-7396

Zhang X, Yan X, Gao P, Wang L, Zhou Z, Zhao L (2005) Optimized sequence retrieval from single bands of temperature gradient gel electrophoresis profiles of the amplified 16S rDNA fragments from an activated sludge system. J Microbiol Methods 60:1-11 